\title{
Crime science: editorial statement
}

\author{
Marianne Junger ${ }^{1 *}$, Gloria Laycock ${ }^{4}$, Pieter Hartel ${ }^{2}$ and Jerry Ratcliffe ${ }^{3}$
}

Imagine criminally active drug addicts or repeat offenders stealing from cars or houses. Do you think these criminals check the stock market before committing an offence? The vast majority of active offenders do not own shares and therefore do not need to keep up to date with the Dow Jones index. However, Sidebottom et al (2011) demonstrate a very close relationship between monthly ups and downs of the copper price as traded on the London Metal Exchange with the extent of theft of copper from the UK railway system. Apparently, although copper thieves may not have been aware of the metal exchange dealings, their behavior reflected the price of the copper on the official market to a remarkable extent. Researchers in Australia found similar results with respect to petrol (Moffatt \& Fitzgerald, 2006) but in this case the petrol theft tracks the price of petrol at the pumps.

At a time when the life sciences discover more and more about the genetic foundation of antisocial behavior (Moffitt, 2005; Rhee \& Waldman, 2002) it is also important to remember that simple but powerful economic incentives such as the market price of specific goods drive theft up and down.

These market prices are one aspect of the environment in which we all live and work. Price is an element of the macro-economic environment that, as shown, has a strong impact on crime. In addition to this, many other types of situational factors can play an important role. The design of physical space is one such factor. For example, Breetzke (2012) found that suburbs at greater altitudes in Tshwane (South Africa) were consistently found to have lower burglary rates. What could be the potential mechanisms explaining this relationship? A possible explanation is that altitude is linked to road structure, and that places at higher altitude are less easily accessible and are therefore less familiar to offenders. Consequently they are less likely to be the focus of burglary. Australian research has identified the management and layout of pubs and bars can predict alcohol-fuelled violence (Graham \& Homer, 2008).

\footnotetext{
* Correspondence: m.junger@utwente.nl

'Department of Public Administration, Institute of Governance Studies (IGS), University of Twente, Drienerlolaan 57522 NB, Enschede, The Netherlands Full list of author information is available at the end of the article
}

The aim of crime science is to study how the environment in this broad sense - affects crime, aggression and disorder.

Subtle psychological aspects also play a role in crime. A study by Wortley and McFarlane (2011) investigated whether an object placed close to other objects was better protected than a similar object on its own. This question was studied in a university library, where cards are necessary to make photocopies. They can easily be stolen when clerks are not paying attention. The research question was: Is a photocopy card that is 'forgotten' next to a pile of books stolen as often as a photocopy card that is lying alone? Wortley (2011) showed that a card next to a pile of books is 'protected' and stolen less often than a card lying alone. The researchers argue that the concept of guardianship explains their findings: the combination of the card next to pile of books send 'guardianship cues' that the card and the pile belong to a specific owner who may come back to get his belongings.

These studies challenge the traditional assumption that society is divided into good guys and bad guys, and that bad guys are the cause of crime. As Cook and Ludwig put it: The simplistic notion that crime is proportional to the number of "criminals" provides no more illumination than asserting that farm output is proportional to the number of "farmers." (Cook and Ludwig 1996). In farming, production depends on the weather, the means of production, market prices and a host of other factors. Similarly, crime depends on a lot of factors independent of the number of good and bad guys (Wortley \& Mazerolle, 2008).

These findings are fascinating in themselves. But the interesting point is that this sort of information helps us to design crime prevention into our social structure. Changing the environment can improve behavior without changing the person. Crime science is about how to prevent these behaviors in the smartest and most discrete way possible such that the undesirable behavior becomes less likely. These environmental changes can be performed at many levels, and in many ways.

For example, most prisoners, when released, go back to their criminogenic environment and to some extent this accounts for the high reconviction rates that we see. Kirk (2009) investigated what happened with prisoners who could not go home after Hurricane Katrina 
damaged their homes in 2005 were relocated elsewhere after their sentence. He found that moving away from former geographic areas substantially lowered a parolee's likelihood of re-incarceration (Kirk, 2009).

In demonstrating the relevance of technology to crime control Rauch (Rauch et al. 2011) carried out a randomized experiment investigating whether a program to require recidivist drunk drivers was effective in reducing subsequent alcohol-related traffic violations. The driver must blow into the device and the vehicle will start only if they are below the legal alcohol limit. A control group received customary sanctions. The researchers concluded that the 2-year administrative ignition interlock license restriction program reduced the incidence of a subsequent alcohol-impaired driving offense by $36 \%$ during the intervention and $26 \%$ during the 2-year post-intervention period.

Finally, Bowers et al (2004) investigated burglary prevention in a high risk neighborhood where gates were placed to block the rear entry to houses through their back-yards. Their study showed an overall reduction in burglaries of $37 \%$. The scheme did not displace burglaries: on the contrary, burglary rates also decreased in the adjacent neighborhoods. In fact many studies have shown similar 'free rider' effects (Guerette \& Bowers, 2009).

The important lesson from crime prevention studies, similar to those described above, is that the environment can be changed by altering urban layout or building design, through technical innovations, policy or organizational changes (Clarke, 2004) and any one of these changes can result in a reduction in crime. This means that a range of disciplines have an important role to play in crime prevention.

We have talked so far about the ways in which science and technology can contribute to crime control. The role of science in relation to the detection of crime is much more familiar and also forms an important part of crime science. This is largely the domain of the forensic sciences which includes DNA developments, fingerprinting, ballistics imaging and recent innovations in geoforensics (Morgan \& Bull, 2007).

The importance of all these sciences to crime reduction is, to us, the reason to start a new journal. We wish to encourage scientists to think about the many ways that their expertise can be used to reduce crime and to actively integrate disciplines in the 'smart fight against crime'. We aim to bring together engineers and architects with psychologists, criminologists and other disciplines that can contribute to this goal. We believe crime prevention and detection will benefit from this common dialogue.

What research challenges do we want to bring to the attention of our readers? The list is long. In addition to the need for better and more effective bomb detectors and the associated paraphernalia of counter terrorism we are also interested the more mundane offences that are so troubling to communities - vandalism, graffiti, car crime, burglary. We are interested in economic crime and fraud; in how to reduce the opportunities to offend provided by new technologies such as the Internet; in how to capitalise on what we know already from other disciplines such as psychology, design (Hilton \& Henderson, 2008), economics (Taniguchi et al. 2009), forensic science (Sapse \& Kobilinsky, 2011), geography, computer science (Amran et al. 2010), complexity science (Johnson, et al., 2011) and the broad field of engineering. Wortley's recent book (Wortley 2011) which reviews the field of psychology from a crime control perspective provides an excellent example of what we have in mind.

On these subjects and all other crime science issues we invite those of you with an interest in preventing and detecting crime to send us manuscripts for publication. Obviously, we are interested in articles that summarise research findings, but we are also interested in systematic reviews. We invite practitioners, police officers or policy makers, to provide us with short contributions that describe interesting case studies, problems or questions.

Finally we'd like to give just a few but important guidelines on style. A research article should have one clear problem to address, with everything subsidiary to that. All contributions should be well written and concise, but not so concise that only a few experts can enjoy reading them. When you write your article, please bear in mind that Crime Science is a multi-disciplinary journal and that we hope it will be as interesting to practitioners as to academic colleagues from other disciplines!

Please visit our web-site (http://www.crimesciencejournal. $\mathrm{com} /$ ) and we hope to see your manuscripts soon.

\section{Competing interests}

The authors declare that they have no competing interests.

\section{Author details}

'Department of Public Administration, Institute of Governance Studies (IGS), University of Twente, Drienerlolaan 57522 NB, Enschede, The Netherlands. ${ }^{2}$ Faculty of Electrical Engineering, Mathematics and Computer Science, University of Twente, Zilverling building, Drienerlolaan 57522 NB, Enschede, The Netherlands. 'Dept. of Criminal Justice, Temple University, 1115 Polett Walk, Philadelphia, PA19122, USA. ${ }^{4}$ Professor of Crime Science, University College London, 35 Tavistock Square, London, WC1H 9EZ, UK.

Received: 12 April 2012 Accepted: 11 June 2012

Published: 11 June 2012

\section{References}

Amran, AR, Phan, RCW, Parish, DJ, Whitley, JN (2010). Evidential Structures and Metrics for Network Forensics. International Journal of Internet Technology and Secured Transactions, 2(3/4), 250-270.

Bowers, KJ, Johnson, SD, Hirschfield, AFG (2004). Closing Off Opportunities for Crime: An Evaluation of Alley-Gating. European Journal on Criminal Policy and Research, 10(4), 285-308.

Breetzke, GD (2012). The effect of altitude and slope on the spatial patterning of burglary. Applied Geography, 34(0), 66-75.

Clarke, RV (2004). Technology, Criminology and Crime Science. European Journal on Criminal Policy and Research, 10(1), 55-63. 
Cook, PJ, Ludwig, J (1996). ECONOMICAL CRIME CONTROL. Cambridge, MA: National Bureau of Economic Research.

Graham, KM, Homer, R (2008). Raising the bar: Preventing aggression in and around bars, pubs and clubs. Cullompton: Willan.

Guerette, RT, \& Bowers, KJ (2009). Assesing the extent of crime displacement and diffusion of benefits: a review of situational crime prevention evaluations. Criminology, 47(4), 1331-1368.

Hilton, K, \& Henderson, K (2008). Developing criminal personas for designers. Papers from the British Criminology Conference, 8, 175-204. Retrieved from http://www.britsoccrim.org/volume8/11Hilton08.pdf.

Johnson, N, Carran, S, Botner, J, Fontaine, K, Laxague, N, Nuetzel, P, et al. (2011). Pattern in escalations in insurgent and terrorist activity. Science, 333(6038), $81-84$.

Kirk, DS (2009). A Natural Experiment on Residential Change and Recidivism: Lessons from Hurricane Katrina. American Sociological Review, 74(3), 484-505.

Moffatt, S, Fitzgerald, J (2006). The relationship between petrol theft and petrol prices. Crime and Justice Bulletin 101, 1-6.

Moffitt, TE (2005). Genetic and Environmental Influences on Antisocial Behaviors: Evidence from Behavioral-Genetic Research. In J. C. D. T. F. Jeffrey C. Hall \& H. Veronica van (Eds.), Advances in Genetics (Vol. Volume 55, pp. 41-104): Academic Press.

Morgan, RM, Bull, PA (2007). The philosophy, nature and practice of forensic sediment analysis. Progress in Physical Geography, 31(1), 43-58.

Rauch, WJ, Ahlin, EM, Zador, PL, Howard, JM, Duncan, GD (2011). Effects of administrative ignition interlock license restrictions on drivers with multiple alcohol offenses. Journal of Experimental Criminology 7, 127-148.

Rhee, SH, Waldman, ID (2002). Genetic and environmental influences on antisocial behavior: A meta-analysis of twin and adoption studies. Psychological Bulletin, 128(3), 490-529.

Sapse, D, Kobilinsky, L. (2011). Forensic Science Advances and Their Application in the Judiciary System. Boca Raton, Florida: CRC Press.

Sidebottom, A, Belur, J, Bowers, K, Tompson, L, Johnson, SD (2011). Theft in PriceVolatile Markets: On the Relationship between Copper Price and Copper Theft. Journal of Research in Crime and Delinquency, 48(3), 396-418.

Taniguchi, T, Rengert, G, McCord, F (2009). Where Size Matters: Agglomeration Economies of Illegal Drug Markets in Philadelphia. Justice Quarterly, 26(4), 670-694.

Wortley, R (2011). Psychological Criminology: An Integrative Approach Abingdon UK: Routledge.

Wortley, R, Mazerolle, L. (Eds.) (2008). Environmental Criminology and Crime Analysis. London, UK: Willan.

Wortley, R, McFarlane, M (2011). The role of territoriality in crime prevention: A field experiment. Security Journal, 24, 149-156.

doi:10.1186/2193-7680-1-1

Cite this article as: Junger et al: Crime science: editorial statement. Crime Science 2012 1:1.

\section{Submit your manuscript to a SpringerOpen ${ }^{\circ}$ journal and benefit from:}

- Convenient online submission

- Rigorous peer review

- Immediate publication on acceptance

- Open access: articles freely available online

- High visibility within the field

- Retaining the copyright to your article

Submit your next manuscript at $\gg$ springeropen.com 